\title{
Plains Apache Tipis: Residential and Ceremonial Lodges
}

Michelle Stokely

Department of Sociology and Anthropology, Indiana University Northwest

Follow this and additional works at: https://scholarworks.sfasu.edu/ita

Part of the American Material Culture Commons, Archaeological Anthropology Commons, Environmental Studies Commons, Other American Studies Commons, Other Arts and Humanities Commons, Other History of Art, Architecture, and Archaeology Commons, and the United States History Commons

Tell us how this article helped you.

This Article is brought to you for free and open access by the Center for Regional Heritage Research at SFA ScholarWorks. It has been accepted for inclusion in Index of Texas Archaeology: Open Access Gray Literature from the Lone Star State by an authorized editor of SFA ScholarWorks. For more information, please contact cdsscholarworks@sfasu.edu. 


\section{Plains Apache Tipis: Residential and Ceremonial Lodges}

\section{Licensing Statement}

Reproduction, posting, transmission, or other distribution or use of the Journal volume, individual article or any portion of the material therein, in any medium, is permitted strictly for personal, non-commercial purposes via a personal-use exemption under a Creative Commons license granted by JTAH.org, Inc. This license exemption requires, as a condition of its granted permission, proper credit be attributed to JTAH.org as copyright holder (e.g., Journal of Texas Archeology and History.org @ 2015). No part of this publication may be reproduced, posted, transmitted, or otherwise utilized or distributed in any form by any means or method for commercial purposes without the express written consent of the Publisher.

Inquiries should be addressed to JTAH Publisher, Suite 307, Box 361, 5114 Balcones Woods Drive, Austin, Texas, 78759.

The Journal of Texas Archeology and History.org is an organization dedicated to furthering research, education and public outreach in the fields of archeology and history concerning Texas and its bordering states of Louisiana, Arkansas, Oklahoma, New Mexico and Northern Mexico; a region we call the "Texas Borderlands." The J.T.A.H. is collaborating with the Index of Texas Archaeology and S.F.A.S.U. to distribute their publication library to the general public via free and open-access channels. Visit www.JTAH.org to submit an article. 


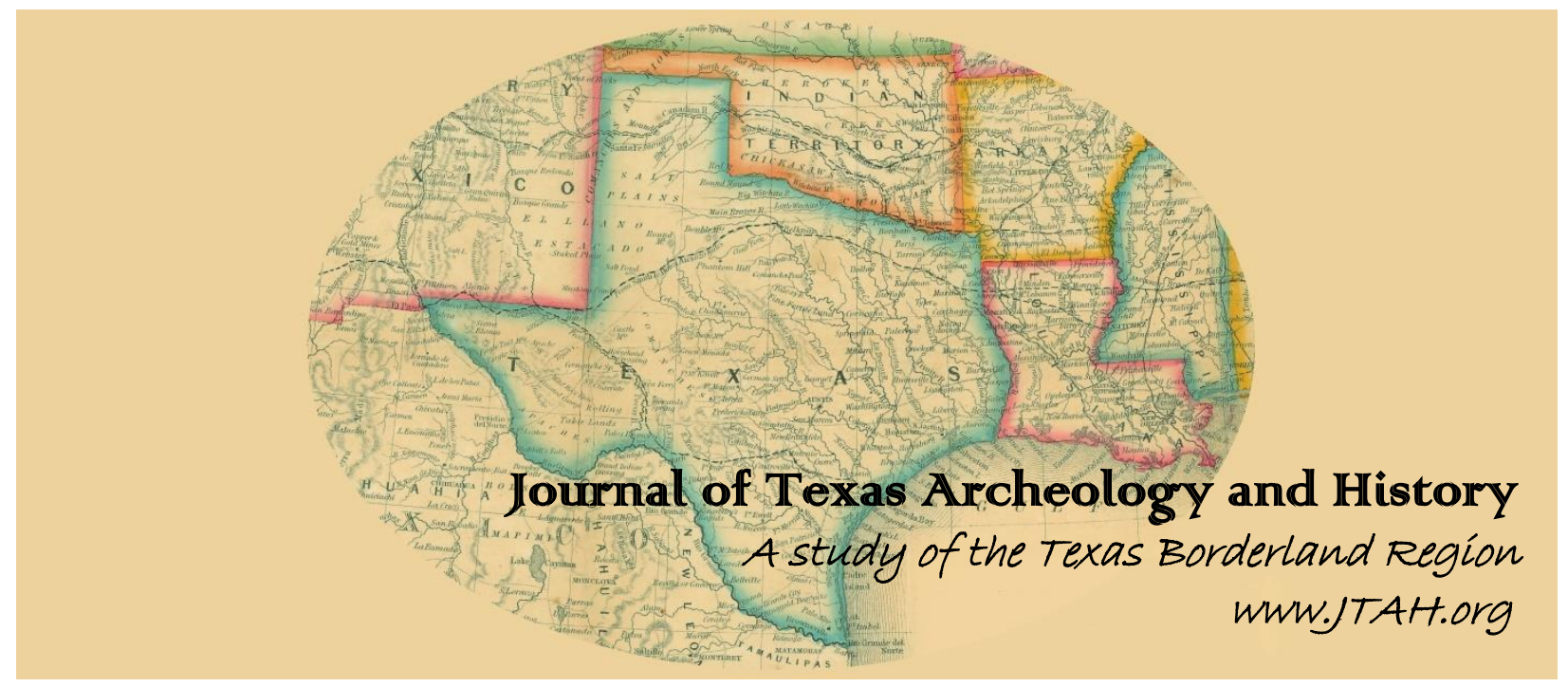

\section{Article Title: PLAINS APACHE TIPIS: RESIDENTIAL AND CEREMONIAL LODGES \\ Author(s): $\quad$ Michelle Stokely}

Original Source: J.T.A.H. Volume 2 (2015), Article 5, pp. 730 98; online 29 December 2015

Recommended Citation: Stokely, Michelle; "Plains Apache Tipis: Residential and Ceremonial Lodges", (2015), Journal of Texas Archeology and History Volume 2 (2015), pp. 73 - 98.

Copyright (c) 2015 by Journal of Texas Archeology and History.org, Inc. All rights reserved. Online/Digital publication: ISSN 2334-1874

The online, digital and print versions of the publication "Journal of Texas Archeology and History" are published by Journal of Texas Archeology and History.org, Inc., a Texas nonprofit IRC Section 501(c)(3) corporation.

Reproduction, posting, transmission, or other distribution or use of the Journal volume, individual article or any portion of the material therein, in any medium, is permitted strictly for personal, non-commercial purposes via a personal-use exemption under a Creative Commons license granted by JTAH.org, Inc. This license exemption requires, as a condition of its granted permission, proper credit be attributed to JTAH.org as copyright holder (e.g., Journal of Texas Archeology and History.org (C) 2015). No part of this publication may be reproduced, posted, transmitted, or otherwise utilized or distributed in any form by any means or method for commercial purposes without the express written consent of the Publisher. Inquiries should be addressed to JTAH Publisher, Suite 307, Box 361, 5114 Balcones Woods Drive, Austin, Texas, 78759.

The Journal of Texas Archeology and History.org is an organization dedicated to furthering research, education and public outreach in the fields of archeology and history concerning Texas and its bordering states of Louisiana, Arkansas, Oklahoma, New Mexico and Northern Mexico; a region we call the "Texas Borderlands." The J.T.A.H. is collaborating with the Index of Texas Archaeology and S.F.A.S.U. to distribute their publication library to the general public via free and open-access channels. Visit www.JTAH.org to submit an article. 


\title{
PLAINS APACHE TIPIS: RESIDENTIAL AND CEREMONIAL LODGES
}

\author{
Michelle Stokely
}

\begin{abstract}
For many Americans, tipis symbolize the nomadic Native American culture and lifestyle. This understanding has been so extensively advanced by paintings, advertising, films, and television that tipis have come to be associated with Native American groups in almost all geographical regions. Tipis were, however, an integral part of residential and ceremonial life in the Great Plains where both construction and use were closely tied to indigenous social organization, politics, war, and spirituality. Among the Kiowa and Plains Apache, residents of the Southern Plains, some tipi covers were painted to reflect war deeds or spiritual blessings. This paper examines the construction, decoration, ownership, and destruction of historic Plains Apache tipis, as well as modern uses of the iconic structures.
\end{abstract}

\section{INTRODUCTION}

Easily transported tents, made from abundantly available bison hides, were an important aspect of life for both nomadic Native American hunting tribes and sedentary horticulturists who also participated in extended hunting activities. Written descriptions of tipis can be found in early European travel narratives, military reports, and other historical documents. Additionally, anthropologists working with Native American community members collected tribal knowledge about the construction, transportation, and use of these mobile structures, as well as associated decorative symbolism. Unfortunately, such valuable information is not available for all Plains tribes. Compared with other tribal groups, less is known about Naisha (Plains Apache) culture, primarily due to the small size of this community and their infrequent contact with Euro-Americans until the reservationera. Treaties and other governmental documents provide a general outline of Naisha tribal leadership and territorial movements, but little discussion of indigenous social life or material culture. Fortunately, Plains Apache elders entrusted some of this valuable information to anthropologists James Mooney in the late 1890s, J. Gilbert McAllister in the 1930s, and University of Oklahoma students in the 1960s. These primarily unpublished sources make it possible to better understand Plains Apache culture, social organization, and spirituality, as well as their use of tipis.

\author{
JOURNAL OF TEXAS ARCHEOLOGY AND HISTORY \\ VOLUME 2:73-98 \\ THE ONLINE PUbLICATION JOURNAL OF TEXAS ARCHEOLOGY AND HISTORY (ISSN 2334-1874) \\ IS PUBLISHED BY JOURNAL OF TEXAS ARCHEOLOGY AND HISTORY.ORG. \\ COPYRIGHT (C) 2015 JOURNAL OF TEXAS ARCHEOLOGY AND HistORY.ORG. ALL RIGHTS RESERVED.
}




\section{THE PLAINS APACHE}

Several Apachean-speaking groups, the ancestors of today's Naisha, Lipan, and Jicarilla tribes, lived in or near the Great Plains prior to the arrival of Europeans. Unfortunately, contact records were not always precise and different names were applied to various tribal groups, making it difficult to accurately identify specific Native communities. Spanish accounts made reference to the Querchero, pre-horse Plains Apacheans living in the Southern Plains as well as bands of Lipan Apache residing in Texas and Northern Mexico (Chebahta and Minor 2007:8-9, Gunnerson 2001:239; Opler 2001:941943). Perhaps the earliest recorded descriptions of Plains Apachean people can be found in materials produced by members of Coronado's 1541 expedition into eastern New Mexico and the Texas panhandle. These records indicated that the expedition encountered some Apache when they

came to a settlement of Indians who are called Quercheros, who travel around with these cows...They have little field tents made of the hides of the cows, tanned and greased, very well made in which they live while they travel around near the cows, moving with these. They have dogs which they load, which carry their tents and poles and belongings (Newcomb 1969:145).

Apache people were also encountered by Don Alonso de Onate's expedition from the northern Spanish colony of New Mexico into the Southern Plains in the fall of 1599. Along the way expedition members saw buffalo and met Native people who traded meat, hides, and salt with the Taos Pueblo. The Spanish also observed several villages, located near the Canadian River in present day Colorado, noting:

there were fifty tents made of tanned hides, very bright red and white in color and bellshaped, with flaps and openings, and built as skillfully as those in Italy and so large that in the most ordinary ones four different mattresses and beds were easily accommodated. The tanning is so fine that although it should rain bucketfuls it will not pass through nor stiffen the hide, but rather upon drying it remains as soft and pliable as before...the sargento mayor bartered for a tent and brought it to this camp, and although it was so very large, as has been stated, it did not weigh over two arrobas (Bolton 1952:226-227). ${ }^{1}$

The Spanish accounts further described the indigenous lifestyle noting, "they live in rancherias in the hide tents hereinbefore mentioned. They always follow the cattle, and in their pursuit are as well sheltered in their tent as they could be in any house" (Bolton 1952:230).

The Naisha Apache were occasionally mentioned in other European accounts of Native life in the Plains. Several French historical sources reference the Gattacka, a Pawnee term applied to Apache people in the Plains, with similar variations used by the Wichita, Arikara, Omaha, and Ponca (Foster and McCullough 2001:939). These French sources indicated that the Gattacka were participating in the Southern and Central Plains horse trade during the 1600s and 1700s (Mooney 1979:248, 250; Foster and McCullough 2001:927-928). By 1800 American sources, including Lewis and Clark,

\footnotetext{
${ }^{1}$ Approximately 50 pounds (Ewers 1997:67).
} 
affiliated the Plains Apache with the Kiowa, noting that both tribes camped in the Northern Plains (Mooney 1979:157-160, 248, 251). During the mid-1800s the Kiowa, Comanche, and Naisha Apache participated in various treaty discussions with the United States, including the 1867 Treaty of Medicine Lodge Creek that created their shared reservation in Oklahoma's Indian Territory (Hagan 1990:27-44). Subsequent military and Agency records record tribal movements and activities, particularly the Kiowa and Comanche raids into Texas and Mexico, that culminated in the Red River War, 1874. Unfortunately, these documents offer less information on indigenous cultural practices or artistic expressions of the period, although missionary records offer some valuable clues. In 1900 the shared KCA reservation was dissolved by the Jerome Agreement; enrolled tribal members selected, or were assigned, 160-acre allotment parcels for the purpose of farming or stock raising, with the remainder eventually sold to non-Native buyers (Hagan 1990:262-285). Allotment produced significant changes in Native politics, economics, demography, religion and education, but many of the tribal cultural practices, including the social and ceremonial uses of tipis, were maintained into the twentieth century and beyond.

\section{PLAINS TIPIS}

The Lakota term tipi has generally been applied to the conical shaped hide tents used by Native American people living in the Plains. The Naisha Apache term agosbi identified the tipi home, while agosbihi je istree referred to a painted tipi cover. A typical Plains tipi was formed by placing 20 cedar or pine poles, approximately 25 feet in length, in an oval shape around a tripod base, and wrapping them with a cover made from 8 to 12 bison cow hides, ${ }^{2}$ anchored to the ground (Libhart and Ellison 1973:9, 11, 14; Ewers 1978:6-7). Additional features included ear flaps, moved by poles, to direct smoke, as well as a door, wooden ground stakes, and cover lacing pins. Interestingly, there were regional as well as tribal variations in the tipi shape, number of poles used, and decoration. Kiowa and Plains Apache tipis used a three pole foundation, providing greater stability (Laubin and Laubin 1957:17). Regional differences can be seen in the shape of smoke flaps, doors, seam stitching, and method of securing the cover to the ground (IACB 1973:14). Additionally, tipi size gradually increased as Native people acquired horses, and later, light weight canvas. ${ }^{3}$

A variety of wood was historically used for tipis, partially based upon availability. Hardwoods, such as ash or chokecherry were generally selected by Plains people for use as ground stakes and lacing pins (Laubin and Laubin 1957:24), while Naisha ground stakes were made from Western soapberry, which was also used for canvas wall tent poles after allotment (Jordan 2008:160). Southern Plains Native people acquired lodge-pole pine by traveling to the Black Hills or the Rocky Mountains, but also used locally available western yellow pine and red cedar. The Plains Apache generally preferred eastern red cedar harvested in the Wichita Mountains of Southwest Oklahoma for their tipi poles. Women would select the trees, while men cut them; poles would be brought to camp where they were cleaned and dried for two weeks (Saddleblanket 1967:21-23). Broken poles could also be

${ }^{2}$ The Smithsonian collection includes an Arapaho bison tipi cover collected in 1874. This lodge was made using 14 hides (Ewers 1997:68-69).

${ }^{3}$ The hide cover for a tipi with a diameter of 20 feet weighed 100 pounds, while a 30 -foot canvas cover weighed just 55 pounds (Laubin and Laubin 1957:121; Vestal 1957:14). 
temporarily replaced with cottonwood until new cedar poles were obtained (Jordan 2008:147-148, 154). However, poles were sufficiently scarce that the Apache valued one pole equal to five horses (Rosoff 2011:9).

Plains tipis were generally made by several women working under the direction of an older, more experienced woman (Laubin and Laubin 1957:18-119), while Cheyenne and Arapaho tipi covers were made by members of a specialty society, the tipi-makers guild (IACB 1973:14). For their tipi covers, Apache women used 8 or 10 buffalo hides, with the heads trimmed off, and sewn together with sinew (Chaletsin 1961a). Kiowa and Apache women preferred summer killed bison hides, without thick winter hair, which were easier to process (Ewers 1978:7). Cleaned hides were smoked to improve waterproofing; as they aged, hides became darker and eventually needed to be replaced. Plains tipis included hide or canvas interior liners, known as dew cloths, to direct air drafts, reduce condensation, and offer privacy (Laubin and Laubin 1957:48-49). Liners were often decorated with painted designs (Laubin and Laubin 1957:49, 55; Zeller 2011:83). Tipi doors were made from bison hide, blankets or canvas, and were occasionally painted (Laubin and Laubin 1957:44-45). After the decline of the Plains bison herds in the late 1800s, Native people turned to domesticated cow hides and canvas to make covers and liners, and today modern tipis are made from strips of light weight canvas sewn together (Laubin and Laubin 1957:25-32).

The majority of tipi covers were left plain, although some covers were specially painted by men to reflect war deeds or religious concepts that had been acquired in a dream. John Ewers estimated that perhaps only 20 percent of Kiowa and Apache tipi covers were painted; these recognizable lodges were owned primarily by leading men, but could be inherited within family lines (Ewers 1978:8). As with new lodge construction, cover painting was a community activity. Tipi covers were painted by 20 or 30 male friends who were honored with a feast provided by the owner (Laubin and Laubin 1957:167-168; Ewers 1978:7). As tipis aged or deteriorated, covers were replaced with fresh hides and the designs were transferred to the new covers.

\section{PLAINS APACHE SOCIAL ORGANIZATION AND RESIDENTIAL TIPIS}

As previously noted, Plains tipis were constructed and maintained by Native women. The making and raising of a new home was a community event in which the owner provided food, offered prayers, and honored the women who had assisted (Laubin and Laubin 1957:75).

Each Apache tipi was home to a couple and their children, as well as any visiting relatives (McAllister 1935:27), while a widow retained her own lodge as long as she was physically able (Chaletsin 1961b). Apache tribal members camped in family groups, known as kusterae (McAllister 1935:27). Women selected family camp sites that were close to water and firewood, spacing their lodges approximately 30 to 50 yards apart (Chaletsin 1961c) (Figure 1). During the summer months several Apache families camped together, forming a gonka (McAllister 1935:26-27) (Figure 2). 


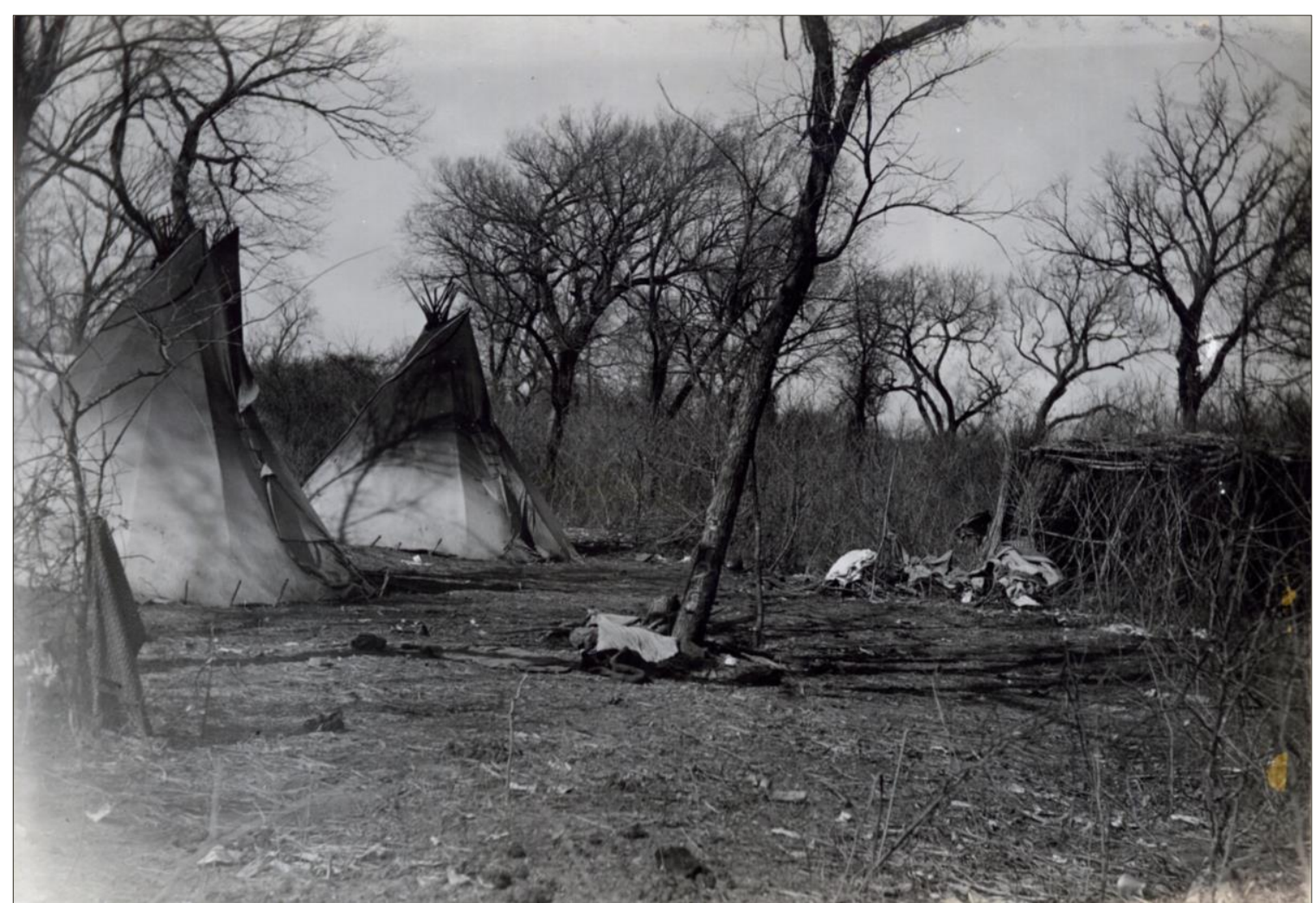

Figure 1: Kiowa or Apache camp near the Washita River, Oklahoma Territory. Photo by Annette Ross Hume, 1901 or 1902. Research Division of the Oklahoma Historical Society.

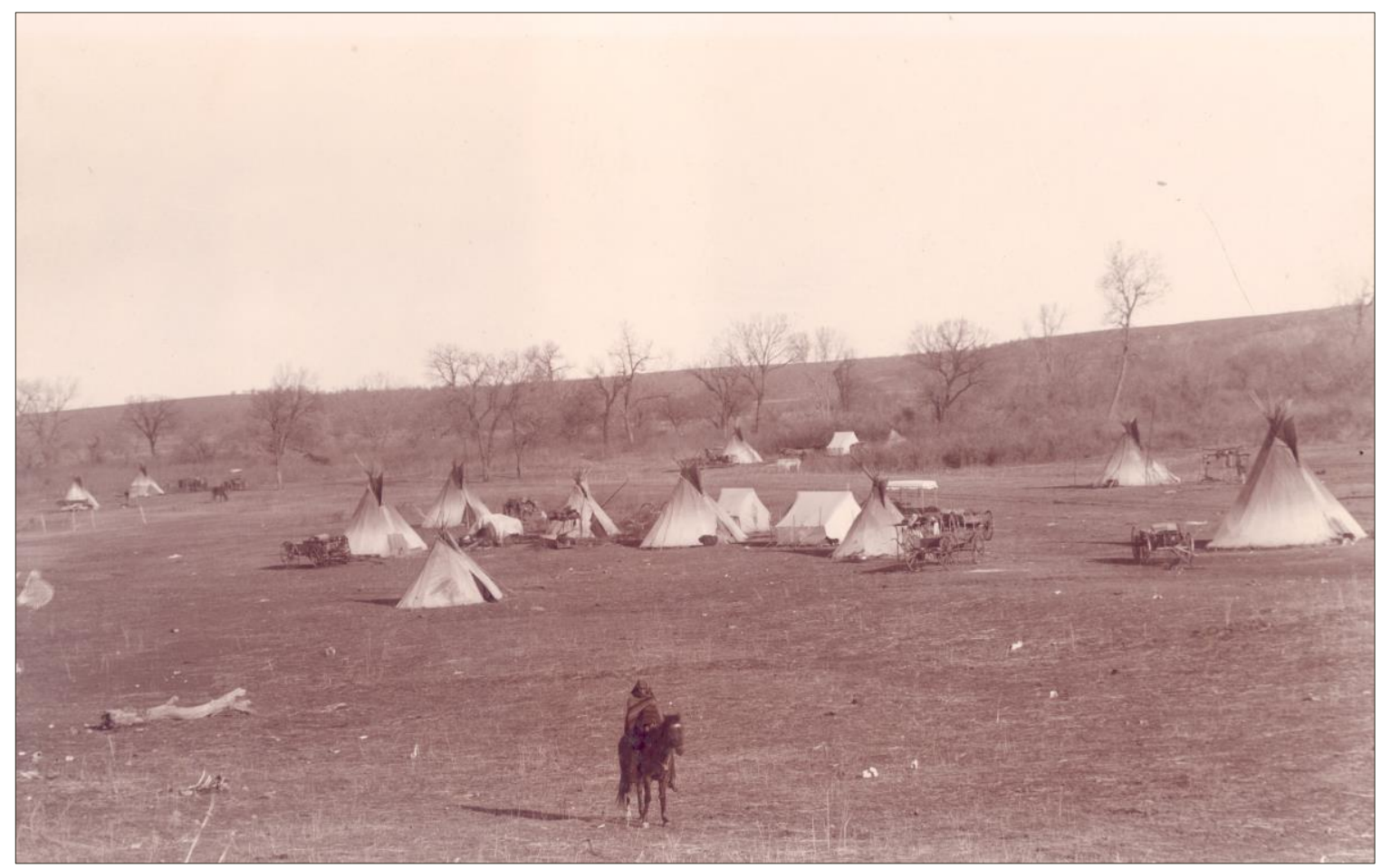

Figure 2: Apache Indian camp on the Washita River. Photo by W.E. Irwin, 1894. Research Division of the Oklahoma Historical Society. 
Apaches joined the Kiowa camp for the annual summer Sun Dance, placing their tipis on the northeastern side of the large camp circle. Years later, the placement of individual tipis within the 1867 Kiowa Sun Dance camp circle would be recalled by tribal elders and documented by Mooney (Ewers 1978:8, 11). This illustration includes the names of 10 Apache men, including several who owned a painted lodge. During the winter, family groups often located their tipis in river bottoms, where they were sheltered from the wind (Figure 3). Willow windbreaks (Figure 4) were occasionally placed around tipis in winter camps (IACB 1973:14-15). The Naisha Apache created their winter windbreaks using bloodweed stalks, fastened to frames made from willow or oak (Jordan 2008:40). These breaks would remain in place, offering protection for campsites that were used repeatedly (Saddleblanket 1967:26-27).

Small tipis were also made by women and their daughters, offering young girls the opportunity to learn valuable sewing skills and to play house (Figure 5), while even smaller tipis were made for their dolls (Laubin and Laubin 1957:141-142). In examining Plains Native social life, Christina Burke noted:

In general, girls' games were played close to the family tipi. Girls played house and practiced cooking, gathering food, sewing clothing, caring for dolls, and moving camp. They set up toy tipis for their dolls and occasionally had play tipis that were large enough to crawl inside. Toy tipis were often adorned just like the family tipi, with beaded rosettes, quilled tabs, and even pictographs documenting the military exploits of male relatives. Girls also had toy travois, the sledges that were used to transport household goods when communities moved camp (Burke 2011:181).

Plains Apache girls also played with toy tipis, using bloodweed stalks for their poles (Jordan 2008:141). In collecting memories of Naisha daily life, McAllister recorded that "most of the day was spent by both boys and girls playing together. They would get sticks and put them up like a tipi. They get a calf hide and put it over. If the parents love their children they will fix a pretty good sized tipi and they play in that" (McAllister 1935:87).

Mobility was an important aspect to life on the Plains, particularly for those tribes that relied upon migratory bison herds. During the summer Apaches moved their camp every week or two as food and firewood became scarce (McAllister 1935:27). Prior to the arrival of horses, Plains Native people used dogs to help move tipi covers and family possessions, aided by a travois made from smaller tent poles. Later, tipi poles were attached to either side of horses, although the dragging motion tended to wear down the poles' ends, hastening the need for replacement. In the late reservation-era, Native people were able to move large tipis, poles, and household items with wagons and teams of horses (Laubin and Laubin 1957:124). After allotment, equipment was occasionally shipped long distances in railroad cars. In 1912 several Kiowa and Plains Apache families traveled south from Oklahoma to participate in the Waco, Texas Centennial, held at the Cotton Palace. Alonzo and Rose Chalepah, as well as their two year old son Alfred, attended this event. Years later Alfred recalled: 


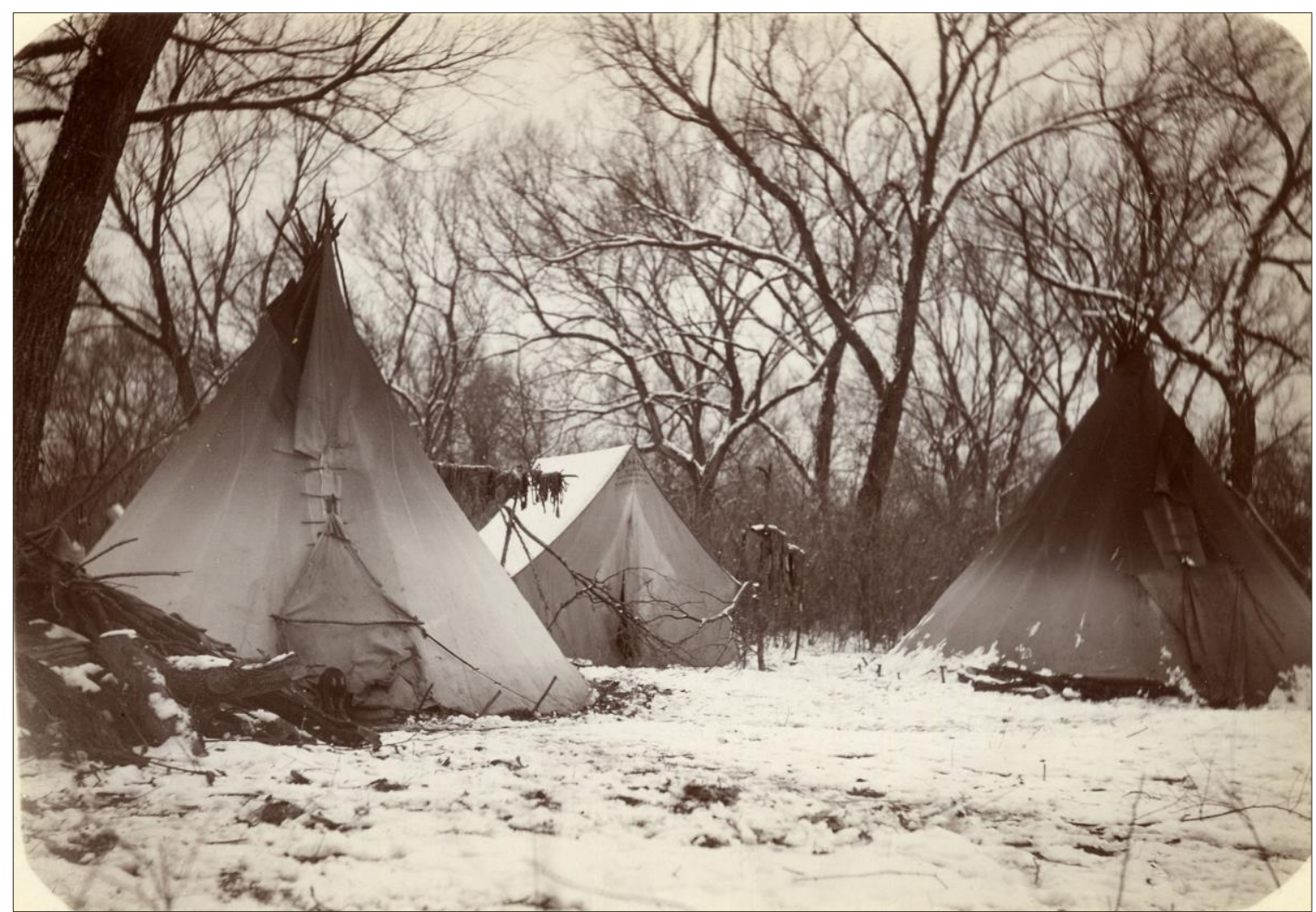

Figure 3: Kiowa winter camp. Photo by Annette Ross Hume, 1901 or 1902. Research Division of the Oklahoma Historical Society.

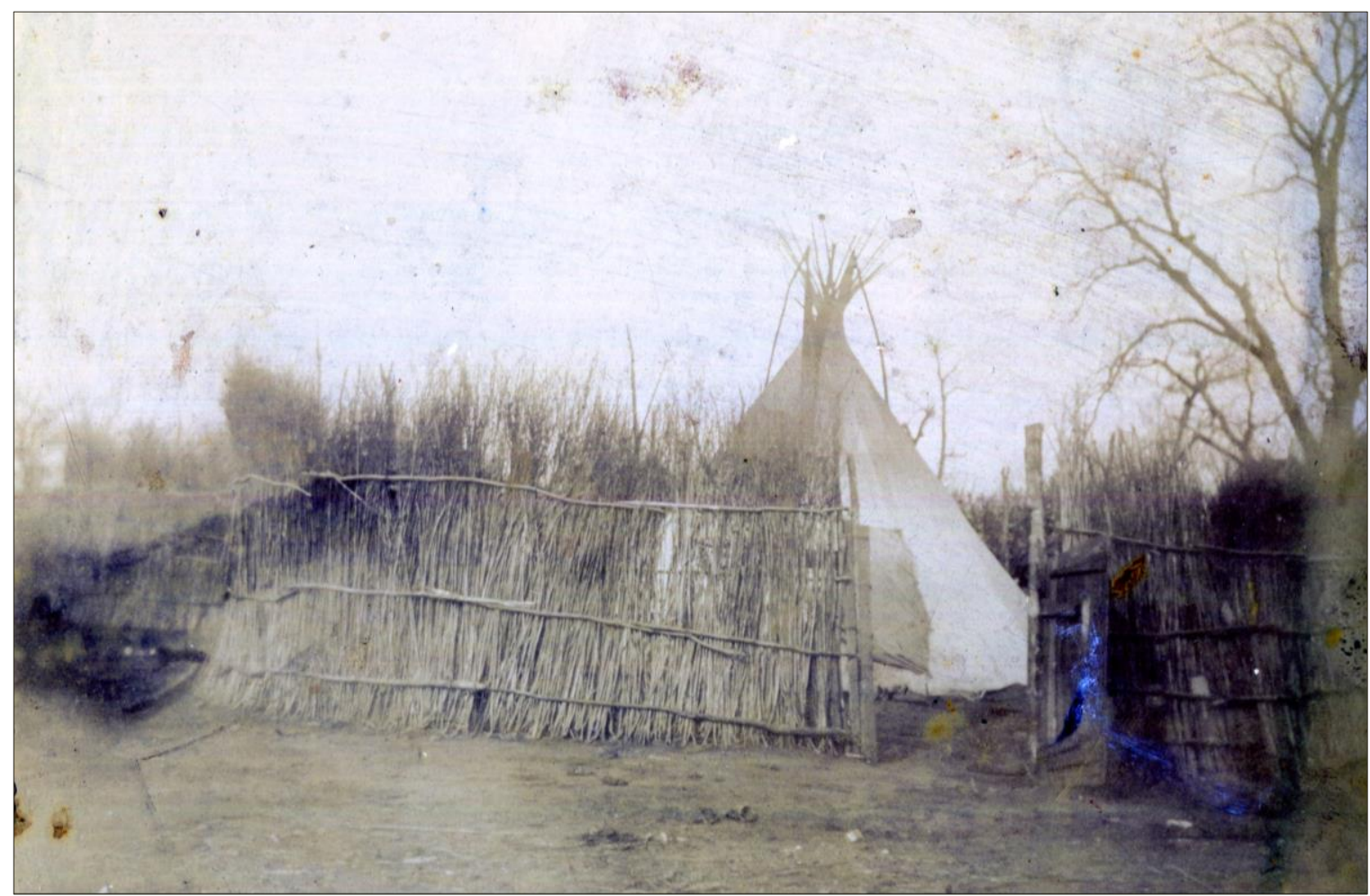

Figure 4: White Buffalo's Kiowa tipi with winter windbreak. Photo by Annette Ross Hume, 1901 or 1902. Research Division of the Oklahoma Historical Society. 


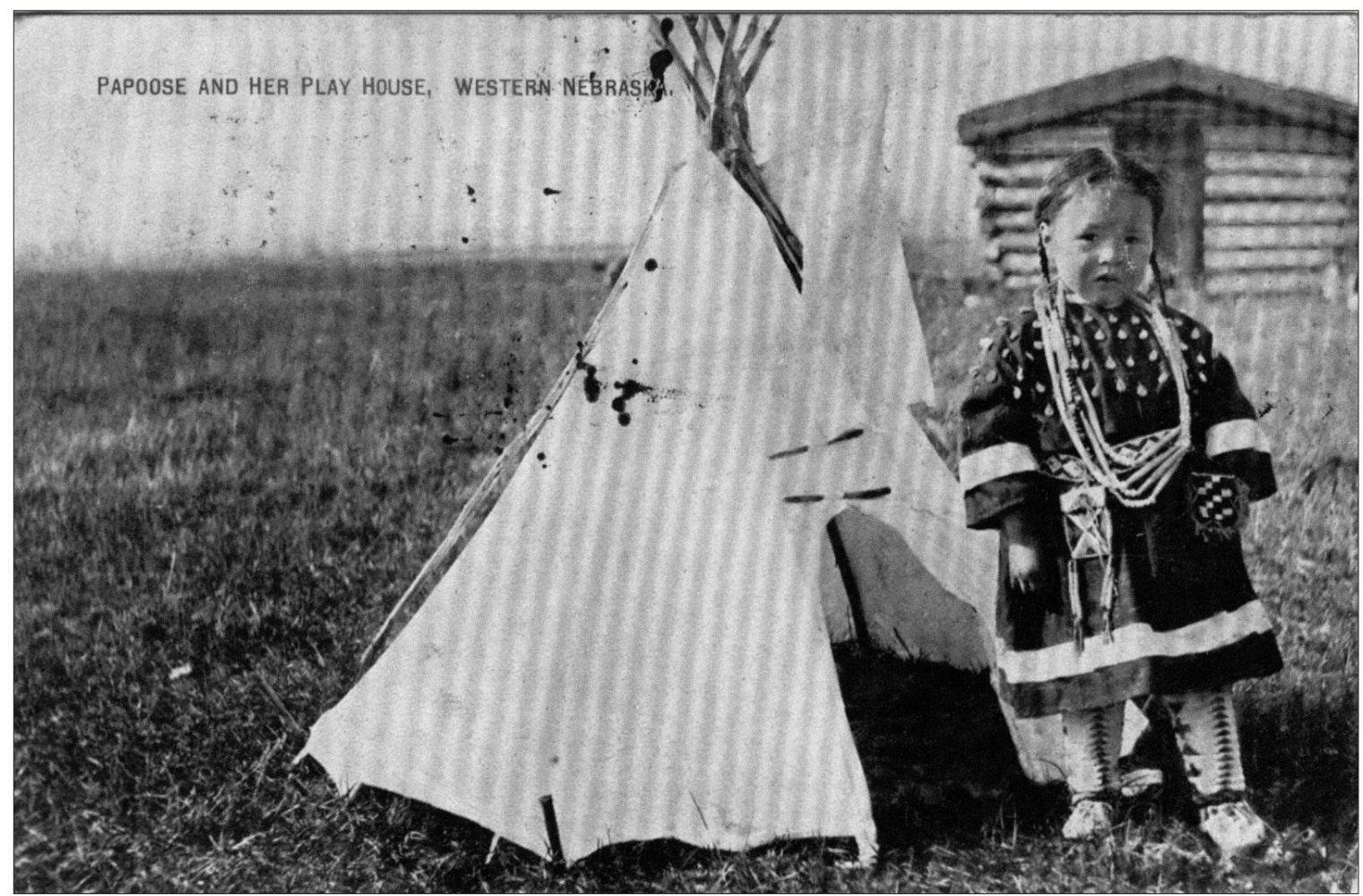

Figure 5: Postcard of child, possibly Cheyenne or Lakota, with play tipi. Postmarked Alliance, Nebraska. June 26, 1909. Collection of the Author.

Waco [Texas] was havin' centennial and I think about ten [Kiowa] families and my parents, the only Apaches that was involved. They got [railroad] coach, the one that carries packages and mail. [George Gert] said bring your tipi poles, tipi, beddin' and what you need, said it's gonna' be a one month event. That's the way I understood it. My father had to haul the poles to town and we had to load up those coaches. They set one day to load up our equipment and that's the story that my dad told me. It took about three days to get to Waco. When we got to Waco they help us unload; they had wagons to unload our equipment, tipi pole and all that stuff and we camp there. (A. Chalepah Sr., personal communication, August 3 and September 12, 2000).

Apache families also traveled by horse drawn wagons, transporting camp materials throughout the region. Today the small number of tipis owned by Apache families are moved using pickup trucks and trailers.

\section{MOONEY'S KIOWA AND NAISHA RESEARCH}

A better understanding of Southern Plains Native people is due to the work of anthropologist James Mooney who collected important details about Kiowa and Plains Apache tribal history, social organization, and material culture. Mooney began working for the Bureau of American Ethnology in 1885; in 1891 he traveled to Indian Territory to continue his studies of Cherokee culture, as well as to conduct an investigation of the Ghost Dance (Moses 1984:54). By 1895, Mooney had begun his 
research on several aspects of Kiowa and Apache culture, including language, calendars, painted tipis, and war shields (Moses 1984:97). To accomplish this work, Mooney interviewed a number of tribal elders, recording personal narratives as well as explanations of historic events and heraldic designs. Through his research, Mooney learned that

Ownership of a painted tipi could only be transferred to a blood relative or a relative by marriage. Because the supernatural power associated with the tipi was the property of the family, the members were reluctant to allow it to be given outside the family, fearing that death or misfortune would be visited on them. Occasionally, but only rarely, a painted tipi was loaned to a relative with permission to make it once and live in it until it wore out, but without the right to renew it or claim it afterward.

Blessed with supernatural power, painted tipis were treasured by their owners, who usually lived in them for many years. Thus an owner became closely identified with the lodge in which he lived. Indeed, some owners came to be called by the names of their tipis (Powell 2013:2:148-149).

Mooney's work was significantly advanced by the contributions of Silver Horn, a Kiowa artist, who drew many of the tipi and shield designs in Mooney's notebooks and also participated in Mooney's examination of Kiowa pictorial calendars (Greene 2009:17). Kiowas occasionally included images of painted tipis in their ledger art, as well as in their summer and winter count historical calendars. These art forms have been well discussed by Candace Greene (2009), Joyce Szabo (2007, 2011) and other scholars. One possible Apache painted tipi appears in a ledger art scene drawn by the Kiowa artist Wo-Ha. This illustration depicted a mixed camp at the Treaty of Medicine Creek and featured several painted Kiowa lodges, Wichita grass houses, and one tipi painted in yellow wedges (Harris 1989:92-93). Curiously, this yellow wedge lodge is reminiscent of a tipi illustration attributed to Alfred Chalepah's paternal grandfather Itselpa, also spelled Zelspa (Mooney MS 2538 Box 2, F3). ${ }^{4}$

Inspired by the information he had collected, Mooney conceived of a project in which small painted model tipis, as well as miniature shields on tripods, would be made and arranged in a camp circle recalling the Kiowa Sundance of 1867. Silver Horn and Paul Zotom, another Kiowa artist, constructed and painted the tipi models using deer hide, standing 26 inches high and spread 56 inches wide (Ewers Box 26, F2). Boas' biographer, L.G. Moses described this activity:

It took many hours of delicate labor to fashion a single tipi. All the models were made from wooden dowels, chamois for the unpainted tipis, and buckskin for the painted ones...Mooney had hired several Indians to paint the covers. They worked from colored pencil drawings of the original designs collected by Mooney from informants who had either owned a painted tipi at one time or remembered the designs of others'. The artists used commercial paints rather than vegetable- and mineral-based paints (Moses 1984:109).

${ }^{4}$ A similar painted tipi also appears in Black Bear's calendar marking the summer of 1881 ; perhaps this drawing recorded Itslepa's death (Stokely 2014:354). 
Despite Mooney's plan, only 30 Kiowa and Apache painted tipi models were actually made, with 17 identified as representing Apache covers. Mooney arranged for his tipi models, as well as miniature shields and tripods, to be displayed at the Trans-Mississippi and International Exposition held in Omaha in 1898 (Mooney 1899:147). Mooney also invited a group of Plains Apaches to attend this event where they erected their canvas tipis, enclosing one in a willow windbreak (Mooney 1899:133134). Mooney attempted a similar tipi model project with the Cheyenne and he hoped to display 80 painted and 120 plain models at the 1904 St. Louis Louisiana Purchase Fair, recreating the Cheyenne's 1874 Sundance. Ultimately, however, only 18 Cheyenne tipi models were produced, with 11 subsequently sent to the Field Museum in Chicago (Fagan 1988:262; Powell 2013:2:214).

Mooney never completed his studies of Kiowa, Apache, or Cheyenne heraldic designs, and his work remained largely unpublished (McCoy 1995:69). However, part of the material was used for an exhibit organized by the Smithsonian's Renwick Gallery of the National Collection of Fine Arts. This exhibit displayed 25 of the Kiowa and Apache tipi models, with supplemental information provided by John Ewer's accompanying catalog, Murals in the Round (Ewers 1978). The Kiowa and Apache shield and tipi models commissioned by Mooney are now archived at the Smithsonian's Museum Support Center, located in Suitland, Maryland. Information, including notes, drawings, and photographs about the tipi and shield models, is scattered across Mooney's and Ewer's professional papers, part of the National Anthropological Archives, also located in Suitland, Maryland. A growing number of scholars have used these materials in the past 20 years to greatly expand our understandings of Native life in the Southern and Central Plains. The Smithsonian has recently digitized some of Mooney's material, including drawings of tipis and shields, making them more available to scholars and the public. These illustrations can be accessed at http://anthropology.si.edu/naa/exhibits/kiowa/mooney.htm with the drawing for Itselpa's lodge available at http://sirismm.si.edu/naa/kiowa/08934300.jpg and Daveko's Moon Tipi illustration at http://sirismm.si.edu/naa/kiowa/08934800.jpg

\section{THE PLAINS APACHE MODELS AND DRAWINGS}

In 1904, Mooney discussed tipi and shield designs with a number of leading Apache men, including All Over Medicine (born 1844), Black White Man (1858), Bitsidi (1851), Daho (1853), Daho's brother, Jack (1842), Apache Jim (1864), Saddle Blanket (1848), and Apache John (1849) (Ewers Box 26). Another informant, Pablito Diaz, had been born in Mexico in 1840 but captured in Parral, Chihuahua by the Apache in 1847 (Mooney 1899:136). All of these older men had knowledge or personal experience with painted tipis and war shields. Mooney's interviews elicited information on the traditional religious beliefs that influenced the various designs and informed appropriate social behavior around spiritually powerful objects, such as shields and heraldic tipi covers. Additionally, Mooney's notebooks contained illustrations of several other Apache tipis that were not used for the models; unfortunately, these illustrations contain fewer details. Importantly, the men also provided valuable genealogical information to Mooney, extending Apache social history back into the early 1800 s. 


\section{Tipi Cover Origins}

Mooney learned that the designs painted on Kiowa and Apache tipis and war shields came from a variety of spiritual sources; for example, Old Man Tipi Pole's lodge cover was believed to have been the result of mescal use by Bilatsashi (also spelled Bilatzachai) sometime before 1861, while Itselpa's tipi design was influenced by peyote (MS 2538, Box 2 F3, F46). Interestingly, Mooney's notes generally do not record the precise details of the dreams or visions that produced the various designs; likely the specifics were unknown to his informants in the 1890s, or they did not possess the right to reveal such powerful information. When Mooney consulted with Apache John about the origins of his grandfather's lodge design, John indicated that he did "not know how he got it but know [it] was when he went pray on hills" (MS 2538 Box 2, F3). Another lodge, featuring a bear design, was made following a dream in which the bear himself refused to reveal knowledge about some of the design elements (Ewers Box 26, F2).

Perhaps the best known Apache lodge, the black and red striped Moon Tipi, was dreamed by Daveko I in 1867 and later used by his son Daveko II. ${ }^{5}$ McAllister subsequently learned some of the details of this tipi's origins:

Daveko's father had dreamed of this tipi after a Klintidie dance...They had danced four days and nights without sleep. On the fourth night at midnight, Daveko's father walked out on the prairie for the rest of the night. Toward morning he fell down and went to sleep and had the vision of his tipi...The power who gave it said, "I'm favoring you with this tipi which will never fall down even in the worst storm. Also you will not die of anything but old age." In the worst storm the relatives would come to this tipi, which never blew down. (McAllister 1970:45).

\section{Ownership and Inheritance}

As previously noted, Mooney learned that tipi designs could be given away or inherited, but usually within a family. In some instances the gift was acknowledged by an exchange of horses; for example, White Man's mother gave two horses for the right to remake the Bear Tipi sometime after her brother's death in 1870 (Ewers Box 26, F2). Daveko II gave his brother Sunte ${ }^{6}$ a tipi in exchange for horses in 1878. Later this lodge design was passed to Archilta, another brother (Mooney MS 2538 Box 2, F3). Generally designs passed from father to son, although occasionally daughters, brothers, or even sisters inherited them. A yellow tipi dreamed by Bagina was given to his son, Wolf on the Hill, who gave it to his daughter, Growing Old (Mooney MS 2538 Box 2, F3). Another tipi made by Bagina was given to his son, Dayetsisa; later it was passed to Dayetsisa's brother Jeliatlan; and finally it was conveyed to Jeliatlan's son, Spotted Thunder. Taho, Spotted Thunder's son, was born in 1853

\footnotetext{
${ }^{5}$ Daveko I died in 1867 or 1868; Daveko II was born approximately 1818 and died in 1897 or 1898 (McAllister 1970:36).

${ }^{6}$ Also recorded as Soontay (approximately1853-1909), allottment \#932 (Bittle n.d: List of Kiowa Apache Allotments).
} 
and lived in this lodge as a child. Taho did not claim ownership of the design, but he helped to construct the tipi model for Mooney (Ewers Box 26, F2).

An owner could lend a tipi to another tribal member, but this did not include the right to renew the lodge or to claim ownership over the design (Mooney MS 2531, vol 1:95). The dynamics of this restriction can be seen in the contested ownership of the Saye lodge, also known as White Man's Yellow Tipi. This lodge was owned by five generations in White Man's family including his father, Thin Bear (or Poor Bear), one of the Apache headmen who signed the Treaty of Medicine Lodge in 1867. Following Thin Bear's death in 1868, his wife remarried and the lodge design passed to her new husband, Daze, and later to their son, Haschilt, White Man's half-brother, who continued to use the design until 1902. However, ownership of this lodge design was contested and briefly claimed by Belo Cozad, Daze's grandson; the lodge had apparently once been loaned to Cozad's father, but ultimately he did not possess the right to remake it (MS 2538 Box 2, F3).

\section{Cover Designs and Embellishments}

The Saye lodge had the longest remembered lineage, perhaps going back to the late 1700s. It was painted yellow with a red moon symbol on the back and was augmented with feathers. Another old lodge, the Dawokahi Tipi, was dreamed by Apache John's grandfather, and last made in 1860. This lodge was also painted yellow with two red moon symbols, as well as a blue crescent moon. Bagina's Dayetsisa (Rainbow) Tipi, last owned by his grandson Spotted Thunder and made in 1863, was painted red and embellished with three circular rainbow elements. It is possible that these solid color lodges represent the earliest Apache design style and color preferences. Traditionally, the Plains Apache placed great spiritual value on the sun, moon, stars and sky, with the colors yellow and red representing the rising and setting sun. While Mooney's notes do not indicate the meanings or significance of tipi colors, other sources offer valuable clues. McAllister learned that "one such tipi painted a solid yellow was associated with the sun..." (McAllister 1955:168). In 1949 anthropologist Charles Brant interviewed tribal member Joe Blackbear who recalled tipi construction and painting:

Old Man Taho sought permission from the other old people to duplicate the tepee, and when the older people consented, the women began sewing the new tepee. They bought some yellow powder in town and also a red powder...They painted the entire tepee yellow...They did it by mixing the yellow powder with water and rubbing it on with rags. In the old days they used clays for paints. The yellow stood for the yellowish color in the sky at sunrise and sunset (Schweinfurth 2002:53).

Interestingly, two lodges appear to demonstrate a transition from the old to a newer design approach. Instead of being painted with a solid color, these covers were painted in yellow triangular wedges and featured decorated doors. The Batikade lodge was painted in yellow sections with white dividing bands, augmented by buffalo tails. Zselpa's tipi featured yellow, and possibly red, triangles with a blue crescent moon painted near the top. Zselpa (also identified as Itselpa) received this design while under the influence of peyote, and it was last remade by his son, Batikaole, around 1870 (Mooney MS 2538 Bx 2, F3). In contrast, lodges dreamed by Daveko I, as well as other men after 
1867, take yet another approach. These tipi covers were primarily painted in triangular wedge sections using dark blue or red colors and had a crescent moon or red sun design painted near the top. Mooney's notes indicate that at least three tipis were dreamed by Daveko I and featured triangular sections of dark colors, supplemented by crescent moon symbols, while a fourth cover was painted in blue sections and included a rainbow design. All these covers were dreamed during the dance in 1867 and later given to various tribal members. Spotted Thunder also dreamed and painted several covers with dark triangular shapes, including one that featured ten bear paws, last seen in 1866 (Mooney MS 2538 Box 2).

Other Apache tipi covers included figures: a bear, eagles, humans, and images that resemble humans. The Bear Tipi held by White Man's family was particularly distinct; Mooney recorded that this lodge was dreamed by White Man's Kiowa grandfather and depicted a large blue bear hugging the red tipi. It also utilized a bearskin door (Ewers Box 26, F2). Interestingly, this lodge cover was similar to a Blackfoot painted tipi that featured a red bear hugging the lodge, with a bearskin door. In his analysis of this Blackfoot tipi, Ted Brasser has suggested that the design may actually be Tsuu T'ina (formerly referred to as Sarcee or Sarsi), a Canadian Athabascan First Nation, in origin and linked to a story in which a bear fosters a boy and later provides spiritual gifts to tribal members (Brasser 1979:37). Brasser noted the possible connections between the Blackfoot, Tsuu T'ina, Kiowa, and Apache, concluding that similar bear lodge designs may have been the result of contact between the tribes around 1800 (Brasser 1979:35, 37, 39). The Kiowa and Plains Apache had frequent contact with northern tribal groups. Lewis and Clark recorded that the Kiowa and Apache were camped in the Black Hills region in 1805, where they traded horses with Mandan and Arikara villagers (Mooney 1979:251; Rhonda 1984:48, 67). The Apache have ancestral stories that may connect them with the Tsuu T'ina, while Mooney noted that several prominent Kiowa were of Tsuu T'ina descent (Mooney 1979:160). As a result of kinship and trade contact, this bear imagery may have been shared among the various tribal groups.

Only one Apache tipi features human figures; it is painted yellow with two individuals holding a pipe. This design was dreamed by Standing Among Men, while under the possible influence of mescal in 1861, and was passed to his daughter, Make See Plain, in 1862. Mooney's model was made by the original owner's son who lived in the tipi, but did not know the meaning of the design (Ewers Box 26, F2). John Ewers speculated that "the pipe held by the man and boy probably signifies the medium through which powers of the sky were transmitted to the human owners of the tipi" (Ewers, Box 26, Exhibition Labels, 8). ${ }^{7}$ A possible figural tipi cover was dreamed by Daveko II and given to his brother Soontay and later to Achilta; this design includes four ball-topped cone-shaped elements, although Mooney's notes do not discuss their meaning or significance. Other tipi covers that were not recorded by Mooney, but are known to Alonzo Chalepah, included Apache John's Eagle tipi, a Buffalo tipi, and a Star lodge that featured six white stars appearing on a black background (A. Chalepah, personal communication, December 24, 2013).

${ }^{7}$ An alternative explanation is offered by Apache tribal member Alonzo Chalepah, interpreting the design as showing how adults demonstrate leadership and guidance to the tribe's youth (A. Chalepah, personal communication, December 24, 2013). 
Several of the Apache's painted tipis covers were further embellished with eagle feather pendants, buffalo tails, ermine skins, or a small medicine bag placed near the top. Most of the doors were left plain, but a few were decorated with rainbow designs. While the majority of wooden poles were plain, some were stained red with local clay and decorated with red hide, or cloth, streamers. Several of the painted lodges also had an associated war shield placed on a pole or tripod, displayed just outside of the tipi (Mooney MS 2538 Box 1, F38, F46, F85; MS 2538 Box 2, F3). Like the painted tipis, some Kiowa and Plains Apache buffalo rawhide shields were painted with important designs, believed to offer spiritual protection. As with painted tipis, shield designs were dreamed or acquired in visions, often the same ones as the tipi covers, and could be given away to relatives or close friends. Mooney recorded information on the origins and histories of shields (McCoy 1995; 2003a; 2003b) and he also arranged for small models to be reproduced for display with his tipi models. Apache informants, including Apache John, Apache Jim, and other leading men, drew shield designs in Mooney's notebooks, listing their owners and speculated on the design meanings. The men also described the rules for proper shield display, both inside and outside of the tipis.

Unfortunately, Mooney's notes do not include information on the tipis' interior features, such as liners or other decorative elements. In consulting with male informants, it appears that Mooney did not collect information about Apache women's contributions to tipi interiors and decorative elements. ${ }^{8}$ However, Rose Chalepah Chaletsin and Connie Mae Saddleblanket described some of the furnishings, including bedding and willow backrests, to William Bittle and his students in the 1960s (Chaletsin 1961d; Saddleblanket 1967:24-25).

\section{Painted Tipi Social Life}

Unlike ordinary residential lodges, painted tipis regulated Plains Apache social behavior. Mooney's informants discussed a number of rules and taboos associated with these special homes, enhancing our understandings of Apache spiritual concepts. White Man's Bear Tipi was believed to have powerful healing properties that could cure the sick; however, only members of the family were allowed to sleep inside. The Saye lodge, also owned by White Man's family, permitted overnight guests, but only if they left a small bow and arrows as offerings tied to a pole inside the tipi. Without this gift, it was believed the occupants would not be able to sleep. Additionally, if a ceremony was held inside this lodge no one was permitted to leave until morning (Mooney, MS 2538 Box 2, F3). Drums and medicine pipes were not to be taken inside the tipi owned by Standing Among Men, and one of the lodges dreamed by Daveko I did not allow boys to play inside for fear that the owner would be injured while hunting or on a military raid. Apache Jim explained that it was taboo to remove arrows from the Dawokahi tipi prior to smoking. Such taboos suggest that the Apache believed relationships existed between their spiritual universe and everyday lived reality; following these rules helped the Apache to regulate social order and avoid spiritual harm.

${ }^{8}$ Compare with discussions of tipi furnishings and cover embellishments, including porcupine quillwork ornaments made by Arapaho women (Hail 2011:120-130; Anderson 2013:47-54). 
Just as there was a proper way to live with these painted tipis and to pass on the designs to others, there was also a ritual method for disposal of decaying hide covers while retaining ownership rights. Mooney's abbreviated notes indicated:

When simply allow a tipi to lapse, cut out from it a small piece, usually round piece at the upper back where tail or other pendant is inserted and preserve this in a small box and throw the rest away. When [the owner] wish to renew the tipi, give piece to whoever they give the claim to make a new tipi. Throw the piece away; carry it to a distant place, dig a hole to represent a buffalo wallow, hold the piece to the sun and pray: "now I got a new tipi, help me walk straight" then put in the hole and cover with buffalo chips. Owners were advised not to destroy their old poles, but to give them to friends (Mooney, MS 2538 Box 2).

In contrast, some tipi designs were intentionally discarded by their owners. One notable example was Daveko's red and black Moon Tipi, well known among the Plains Apache. Both Daveko I and his son were considered to be powerful medicine men, and this lodge design had been received in a vision following four days of fasting and dancing. Together, these aspects made this lodge particularly powerful. Following the death of Daveko II, his step-son Apache Sam Klinkole ritually discarded the lodge in a process recorded by Mooney. It was "thrown away by spreading flat in a buffalo wallow with a prayer at sunrise. This is the regular Apache way to throw away tipi forever. Sometimes it was put on a hill, spread flat in a hollow dug to represent a buffalo wallow" (Mooney, MS 2538 Box 2). Like the destruction of Daveko II's Moon Tipi, other aspects of Plains Apache culture and religion were also avoided, or intentionally set aside, as community members attempted to exist within the new reality of reservation life.

\section{RESERVATION AND ALLOTMENT-ERA ADJUSTMENTS}

The painted buffalo hide tipis described by Mooney's informants existed in the mid-1800s, but most were not renewed during the reservation-era as Southern Plains Native people gradually shifted to canvas tents and wood houses. To discourage camp life, the United Stated government constructed 10 wooden houses across the reservation, at a cost of $\$ 600$ each, giving them to tribal headmen, including Taha and White Man (Mooney 1979:342-343). Despite pressure to settle, many KCA members continued to use tipis made with canvas. By 1886 only nine Kiowa families resided in wooden houses; these were subsequently abandoned or rented to Anglos (Meadows 2008:148-149). Sixty additional houses were constructed in 1892 (Mooney 1979:364), but Kiowa tribal members still preferred the outdoor life as Baptist missionary Isabel Crawford observed in 1896: "the home of Lucius Aitsan was a little two-roomed cottage...there were two tepees and an arbor in the yard." (Crawford 1998:32-33). Like their Comanche and Kiowa neighbors, most Apaches preferred to live in tipis, tents, and summer brush arbors instead of the government's wooden houses. Apache elder Alfred Chalepah noted that

a lot of people live out in the country and after they start buildin' the road some ask for government houses, that's two room house. A few Apaches got it but [some] don't like [to] 
live in the house, they prefer tent like Apache Stevie. They build him good house....and I don't think he slept one night in it (A. Chalepah Sr., personal communication, September 12, 2002).

When asked about early allotment-era life, Connie Mae Saddleblanket recalled:

We live in tipi. Pretty near all the time. See the government went and furbished two room houses for the people, but we don't live in there. They don't care to live in there. We're just outside all the time in the tipi...We just live in a tipi. That was nice, though. Maybe a house could be not too far, we don't camp too far from the house...I like to stay in the tipi (Saddleblanket 1967:23-24).

The camp lifestyle persisted into the early twentieth century, partially extended as many Native people became landless following the breakup of the commonly held reservation into individually allotted parcels, some of which were immediately sold for much needed cash. As a result, tents and arbors were erected on lands held by relatives. To avoid overstaying their welcome, or to find new sources of firewood and food, many tribal members drifted from place to place much as they had done in the past. Alfred Chalepah, Sr. described his own family's experiences in the 1920s:

My grandpa [Archilta] had two wives; [his] other wife, Me Ka, [was] Mescalero. My mother and her mother live on south side [of his allotment]; they had two tents joined together, and the other [wife] lived on the north side. After my grandmother died, we didn't have no place to go. We live in wagon, go west of Fort Cobb [to visit] Big Man, my father's mother's brother. We go over there and stay in the wagons. We stay there so long and then we go [visit other relatives]. We stay at Big Man's awhile and sometimes we go to Redbone. (A. Chalepah Sr., personal communication, June 13, 2000).

Gradually, canvas wall tents purchased at area hardware stores replaced tipis. Connie Mae recalled: "Mr. Boke... had tents and they buy them over there. ${ }^{9}$ And they don't give too much. I don't know how much they give but anyhow they buy them over there. And they began using tent...just here and there using tipi. Like us, we use tipi, me and my aunt. My folks they use tent" (Saddleblanket 1967:25-26). By the time of his fieldwork in 1933 and 1934, McAllister concluded that painted tipis were non-existent: "only one such tipi has been used recently (fifty years ago), though formerly there were probably more" (McAllister 1955:167). However, McAllister's fieldwork photographs show several plain canvas tipis being used for social gatherings (Figure 6), as well as for Native American Church meetings.

${ }^{9}$ Boake's Stores were located east of Rainy Mountain School, as well as in Anadarko, Oklahoma. The stores sold dry goods, groceries and harness, often on credit (Silverhorn 1967:5; Meadows 2008:298). 


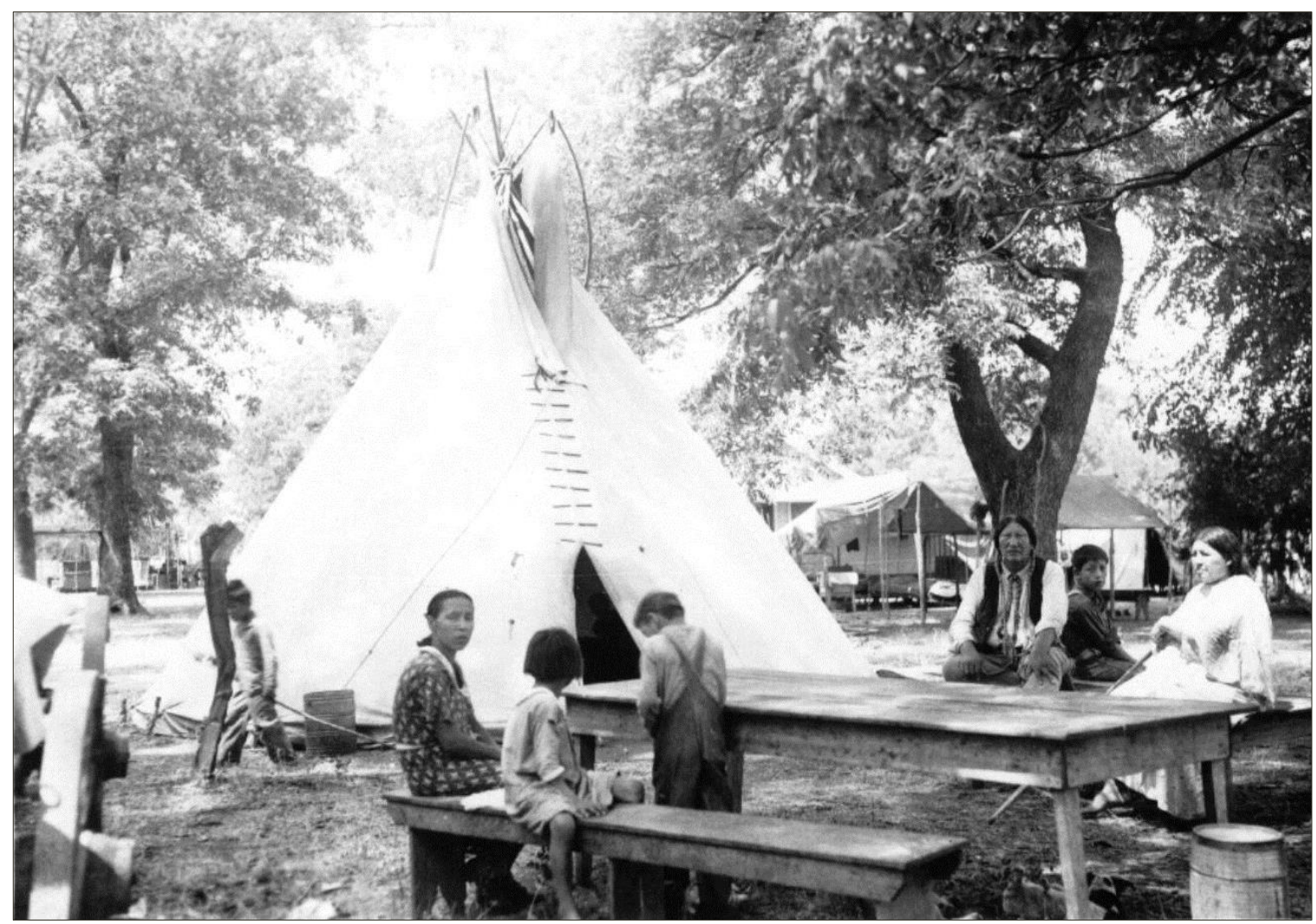

Figure 6: Ben Chaletsin's Tipi and camp. Photo by J. Gilbert McAllister, 1934. Collection of the Author.

\section{SOCIAL AND CEREMONIAL USES OF TIPIS}

In addition to residential activities, tipis were used for ritual purposes including feasting, naming of children, warrior society meetings, and religious ceremonies. Joe Blackbear recalled that his family put up a large tipi and offered a feast when he was given a name in 1878 (Brant 1991:39-41). Another important social gathering initiated Apache children into the Rabbit Society. Here, families celebrated their children's good health by sponsoring a meal and a dance. McAllister reported that "all the children gathered in the tipi of the people who were giving the dinner. The sides were rolled up and the parents and visitors sat around watching...In dancing the children imitated rabbits, hopping up and down with slightly bent knees and with hands slightly cupped and held beside their head in imitation of rabbits ears" (McAllister 1935:92, 93).

Tipis were also used for adult society meetings. Many of the Kiowa and Plains Apache men belonged to warrior groups whose members would host meetings in their own tipis; rolling up the tipi covers provided ventilation during the meetings and allowed community members to witness the proceedings (Meadows 1999:62, 65; Swan and Jordan 2011:152, 156). Interestingly, Kiowa ledger art drawings depict society meetings held inside a tipi (Swan and Jordan 2011:154). McAllister's informants noted that the wives of Apache Manatidie Society members remained outside of the tipi during meetings, although occasionally the cover was also rolled up to allow others to watch the dancing (McAllister 1935:107, 109). Apache Klintidie Society meetings also took place within a tipi 
(McAllister 1935: 215). The Izuwe, an Apache women's society, met in a tipi specially erected by a man who had been successful in war (McAllister 1935: 114).

Historically, the Apache also sought safety and spiritual comfort within special tipis; for example, the homes of the tribe's sacred medicine bundle keepers ${ }^{10}$ were seen as sanctuaries for women who were accused of adultery (McAllister 1935:104). Tipis were used for healing rituals and for Native American Church meetings, offering a quiet place for prayer, songs, spiritual reflection, and also social connection. In his examination of the Native American Church, Weston LaBarre noted that "the first Kiowa meetings took place within a circle of upright poles, with canvas stretched around it, open to the sky." (LaBarre 1971:61). Even in the early part of the twentieth century, new tipi making remained a communal event, requiring the support and assistance of family and friends, as Alfred Chalepah, Sr. recalled:

In [1931 or 1932] my cousin, Ward Archilta, and my father were chosen to raise funds to buy poles and canvas to make tipi. [At] that time they have to borrow; some people don't have tipi so they thought might be good idea to get tipi and poles. If [someone] gonna have peyote meetin' they could have right to use. It didn't take that long, even though money was hard. They ask for canvas, I think the canvas was thirty-two inches [wide]. It's pure canvas, not too heavy or too light. They got almost hundred and twenty-five yards. They got my mother and Old Lady Black Bear and somebody else, those three women, and so they got it together. We felt like we should put it up and break it in, so they got my father to run that meetin' and they got Ward to beat drum...Well, we got it together so we put it up and we had peyote meetin' that night and next day everybody felt good about it. So anytime anybody wants to have peyote meetin' you're free to use it, but bring it back. Yeah, them poles too, ropes and those pots and pans and all that ya know. That's the way we operated. (A. Chalepah Sr., personal communication, September 5, 2000).

In 1949 Charles Brant attended a meeting and observed that "the tipi was made of Sherman duck canvas, several strips being sewn together. It was placed with the door facing eastward. On the inside, buffalo grass was placed around the outer edges and covered by canvas for the participants to sit on" (Brant 1950:215). The same layout continues today; Native American Church meetings now take place within a canvas tipi that comfortably accommodates 30 participants (LaBarre 1971:46). A small number of canvas tipis are owned by individual Apache families (Figure 7), as well as by the tribe, and are borrowed whenever a Native American Church meeting is planned (Brant 1950:217; A. Chalepah, personal communication, November 11, 2013).

Canvas tipis are still incorporated into important community cultural events, such as the Manatidie Blackfeet Society dances and Apache summer youth programs, events that take place in the tribal park located east of Carnegie, Oklahoma (Figure 8). Several of these canvas tipi covers were sewn by sisters Gertrude Chalepah and Irene Chalepah Poolaw, generally regarded as the tribe's last tipi makers.

${ }^{10}$ Tribal members continue to respect these sacred items and have requested limited academic discussion of them. 


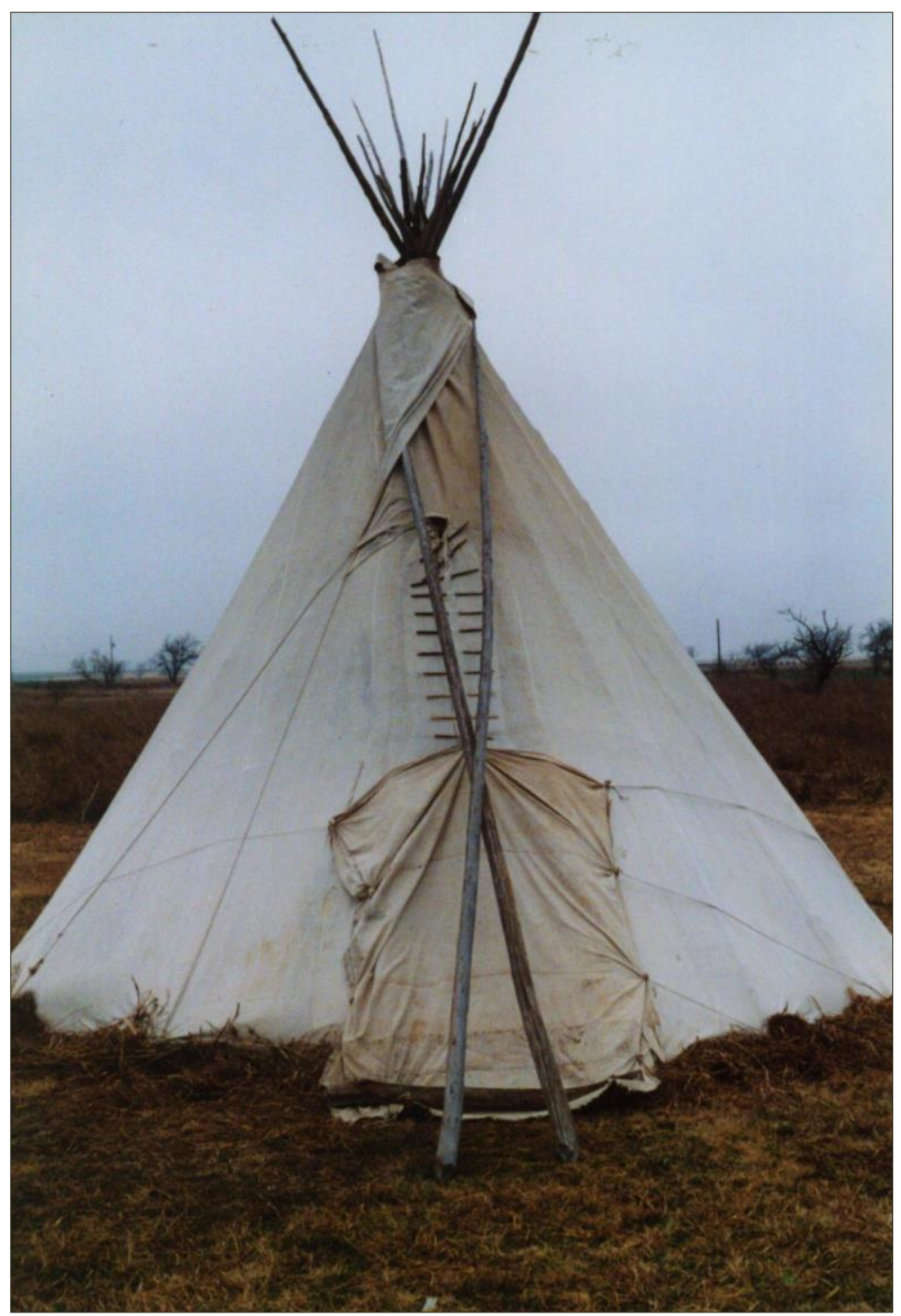

Figure 7: Chalepah family Native American Church tipi with closed smoke flaps. Photo by the Author, December 2002.

\section{REPLICA PAINTED TIPIS}

Contemporary painted tipis can be seen each August, displayed on the grounds of the Southern Plains Indian Museum, located in Anadarko, Oklahoma. In 1973, the Department of the Interior's Indian Arts and Crafts Board worked with the Southern Plains Museum to exhibit 12 tipis made and painted by contemporary Native American artists. This exhibit featured examples of Cheyenne, Comanche, Kiowa, and Plains Apache lodges. Two of the covers were sewn by Gertrude and Irene 


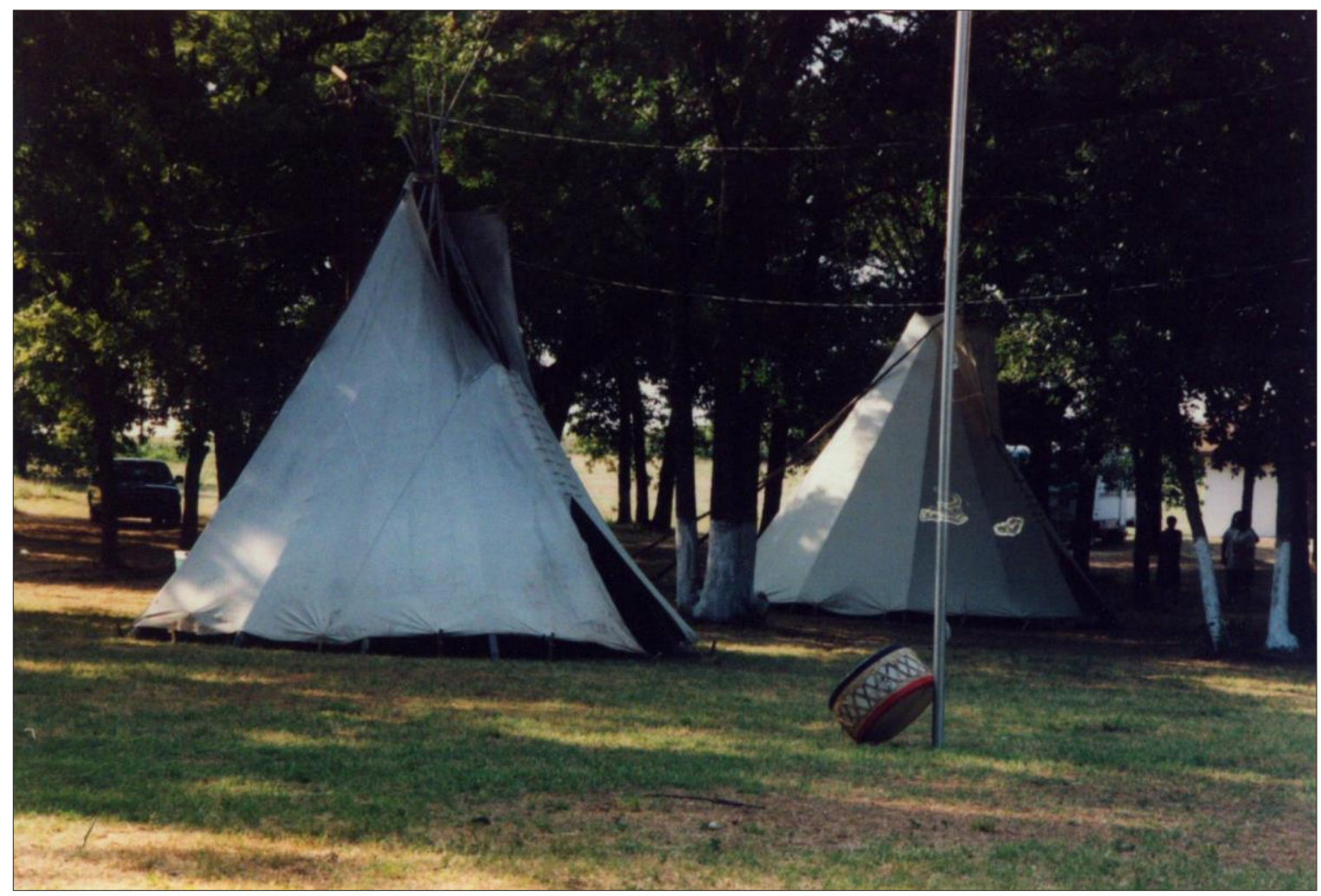

Figure 8: Tipis at Apache youth camp, Photo by Author, Summer 2001.

Chalepah, using a tipi previously owned by Ben Chaeltsin for their pattern (IACB 1973:43). Apache artist Elton Stumblingbear applied latex paint to one canvas cover, replicating Daveko's Moon Tipi (IACB 1973: 26). The Museum continues to erect several of the painted tipis in conjunction with the American Indian Exposition, an annual fair that celebrates food, dancing, and art, as well as contests for the best tipi and brush arbor display (Ellis 2003:156). A photograph of the assembled painted tipis has also been used for a tourist postcard, printed by the Prairie Production Company of Tulsa, Oklahoma, and sold in Oklahoma stores. Once again the iconic structure is offered to the general public as representing Native Americans in Oklahoma; unfortunately, few details are offered on the postcard to inform consumers of the tipi's deeper meanings in Southern Plains indigenous culture. ${ }^{11}$

\section{CONCLUSION}

For mobile bison hunters of the Great Plains, portable hide tents offered a comfortable and efficient home. Native women worked together to construct and maintain the tipi residences, as well as their internal furnishings. But tipis were more than mere homes to Native peoples; they were also important indicators of family size, wealth, prestige, and essential kinship connections. Additionally, they provided leading men with a visual format to express military honors and personal relationships with the spiritual universe.

\footnotetext{
${ }^{11}$ For more discussion of postcards in Oklahoma, see Stokely (2015).
} 
As occupants of the Southern Plains, the Kiowa and Plains Apache embraced a lifestyle that was nurtured and sustained by migratory bison and horse herds. Their material culture, social organization, military societies, and relationships with other Native peoples developed and adapted to meet the challenges and rewards of life in the Plains. For many Kiowa, Comanche, Plains Apache, and other Native peoples, success depended upon supernatural blessings acquired in dreams or visons. Native art forms expressed these important and essential spiritual understandings, and were communicated to others on painted tipi covers and war shields.

By the late nineteenth century, declining bison herds, confinement to reservations, and nonNative influences rapidly altered Southern Plains Native communities. At nearly the same moment in time, anthropologists began collecting cultural information. James Mooney's work with Kiowa and Apache elders has proved invaluable to scholars seeking a better understanding of tribal histories, social organization, family genealogies, military activities, language, and spirituality of the 1800s. Although incomplete, Mooney's research on painted tipis offers us a glimpse into Southern Plains Native life as it transitioned into the twentieth century.

Kiowa, Comanche and Apache people continue to reside in the Southern Plains of Oklahoma. Here they maintain important connections to family, land, and history, while developing and adapting their social institutions, economies, and governmental services to meet the needs of tribal members today. Cultural affiliations, such as the Manatidie Society and Native American Church, help community members to maintain essential connections. Tipis continue to serve as symbols of the historic past, but also function as important markers of cultural continuity into the twenty-first century and perhaps beyond.

\section{REFERENCES CITED}

Anderson, Jeffrey D

2013 Arapaho Women's Quillwork: Motion, Life and Creativity. University of Oklahoma Press.

Bittle, William E.

n.d. List of Kiowa Apache Allotments. William Bittle Collection, Box 2, F7. University of Oklahoma's Western History Library, Norman, Oklahoma.

Bolton, Herbert Eugene (editor)

1952 Spanish Exploration in the Southwest 1542-1706. Barnes \& Noble, Inc., New York.

Brant, Charles S.

1950 Peyotism Among the Kiowa-Apache and Neighboring Tribes. Southwestern Journal of Anthropology 6: 212-222.

1991 [1969] The Autobiography of a Kiowa Apache Indian. Dover: New York. 
Brasser Ted J.

1979 The Pedigree of the Hugging Bear Tipi in the Blackfoot Camp. American Indian Art Magazine 5(1):32-39.

Burke, Christina E.

2011 Growing Up on the Plains. In Tipi Heritage of the Great Plains, Nancy B. Rosoff and Susan Kennedy Zeller, eds., pp.169-192. University of Washington Press, Seattle.

Chaletsin, Rose Chalepah

1961a Construction of Tipis. Interview June 22. William Bittle Collection, Box 2, F42.University of Oklahoma's Western History Library, Norman, Oklahoma.

1961b The Tipi. Interview June 18. William Bittle Collection, Box 2, F42. University of Oklahoma's Western History Library, Norman, Oklahoma.

1961c Arrangement of Camp. Interview June 23. William Bittle Collection, Box 2, F42. University of Oklahoma's Western History Library, Norman, Oklahoma.

1961d Tipi Furnishings. Interview June 23. William Bittle Collection, Box 2, F42. University of Oklahoma's Western History Library, Norman, Oklahoma.

Chebahtah, William and Nancy McGown Minor

2007 Chevato: The Story of the Apache Warrior Who Captured Herman Lehmann. University of Nebraska Press, Lincoln.

Crawford, Isabel

1998 Kiowa: A Woman Missionary in Indian Territory. University of Nebraska Press, Lincoln.

Ellis, Clyde

2003 A Dancing People: Powwow Culture on the Southern Plains. University Press of Kansas, Lawrence.

Ewers, John C.

n.d. Papers of John Canfield Ewers, Series II Research and Subject Files, Box 25 and 26. National Anthropological Archives, Suitland, Maryland.

1978 Murals in the Round: Painted Tipis of the Kiowa and Kiowa-Apache Indians. Smithsonian Institution, Washington D.C.

1997 Plains Indian History and Culture. University of Oklahoma Press, Norman.

Fagin, Nancy L.

1988 The James Mooney Collection of Cheyenne Tipi Models at Field Museum of Natural History. Plains Anthropologist 33(120):261-278. 
Foster, Morris W. and Martha McCullough

2001 Plains Apache. In Plains, edited by Raymond DeMallie, pp. 926-940. Handbook of North American Indians, Vol. 13, William C. Sturtevant, general editor, Smithsonian Institution, Washington, D.C.

Greene, Candace S.

2009 One Hundred Summers: A Kiowa Calendar Record. University of Nebraska Press, Lincoln.

Gunnerson, James H.

2001 Plains Village Tradition: Western Periphery. In Plains, edited by Raymond DeMallie, pp. 234-244. Handbook of North American Indians, Vol. 13, William C. Sturtevant, general editor, Smithsonian Institution, Washington, D.C.

Hagan, William T.

1990 United States-Comanche Relations. University of Oklahoma Press, Norman.

Hail, Barbara

2011 Women's Arts Centered in the Tipi. In Tipi Heritage of the Great Plains, Nancy B. Rosoff and Susan Kennedy Zeller, eds., pp.119-139. University of Washington Press, Seattle.

Harris, Moira F.

1989 Between Two Cultures: Kiowa Art from Fort Marion. St. Paul, Pogo Press.

Indian Arts and Crafts Board (IACB)

1973 Painted Tipis by Contemporary Plains Indian Artists. Indian Arts and Craft Cooperative, Anadarko, Oklahoma.

Jordan, Julia A.

2008 Plains Apache Ethnobotany. University of Oklahoma Press, Norman.

Laubin, Reginald and Gladys Laubin.

1957 The Indian Tipi Its History, Construction and Use. University of Oklahoma Press, Norman.

LaBarre, Weston

1971 The Peyote Cult. Schocken Books, New York.

Libhart, Myles and Rosemary Ellison

1973 Introduction. In Painted Tipis by Contemporary Plains Indian Artists, pp. 7-17. Indian Arts and Craft Cooperative, Anadarko, Oklahoma.

McAllister, J. Gilbert

1935 Kiowa-Apache Social Organization. Unpublished Ph.D. dissertation, Department of Anthropology, University of Chicago, Chicago. 
1955 [1937] Kiowa-Apache Social Organization. In Social Anthropology of North American Tribes, edited by Fred Eggan, pp.99-129. University of Chicago Press, Chicago.

1970 Daveko: Kiowa-Apache Medicine Man. Bulletin of the Texas Memorial Museum 17, November, pp. 30-61.

McCoy, Ron

1995 Miniature Shields, James Mooney's Fieldwork Among the Kiowa and Kiowa-Apache. American Indian Art Magazine 20(3):64-71.

2003a "A Shield to Help You through Life": Kiowa Shield Designs and Origin Stories Collected by James Mooney, 1891-1906. American Indian Art Magazine 28(3):70-81.

2003b "I Have A Mysterious Way": Kiowa Shield Designs and Origin Stories Collected by James Mooney, 1891-1906. American Indian Art Magazine 29(1):64-75.

Meadows, William C.

1999 Kiowa, Apache, and Comanche Military Societies. University of Texas Press, Austin.

2008 Kiowa Ethnogeography. University of Texas Press, Austin.

Mooney, James

n.d. Apache Tipi and Shield Notes. MS 2538, Box 2. National Anthropological Archives. Suitland, Maryland.

n.d. Notes and Drawings on Cheyenne and Kiowa Heraldry, 1902-1906, MS 2531, volume 2. National Anthropological Archives. Suitland, Maryland.

1899 The Indian Congress at Omaha. American Anthropologist, New Series 1(1):126-149.

1979 [1898] Calendar History of the Kiowa Indian. Smithsonian Institution, Washington, D.C.

Moses, L.G

1984 The Indian Man: A Biography of James Mooney. University of Illinois Press, Urbana.

Newcomb, W.W. Jr

1969 The Ethnohistorical Investigation. In A Lipan Apache Mission, San Lorenzo de la Santa Cruz 1762-1771, Curtis D. Tunnell and W.W. Newcomb Jr., pp. 141-180. Texas Memorial Museum, Austin.

Opler, Morris E.

2001 Lipan Apache. In Plains, edited by Raymond DeMallie, pp. 941-952. Handbook of North American Indians, Vol. 13, William C. Sturtevant, general editor, Smithsonian Institution, Washington, D.C. 
Powell, Peter J. (editor and translator)

2013 In Sun's Likeness and Power: Cheyenne Accounts of Shield and Tipi Heraldry 2 Vols. University of Nebraska Press, Lincoln.

Rhonda, James P.

1984 Lewis and Clark among the Indians. University of Nebraska Press, Lincoln.

Rosoff, Nancy B.

2011 Tipi: Heritage of the Great Plains. In Tipi Heritage of the Great Plains, Nancy B. Rosoffand Susan Kennedy Zeller, eds., pp.3-35. University of Washington Press, Seattle.

Saddleblanket, Connie Mae.

1967 Interview March 14. Doris Duke Oral History Collection, 41, T-3. Western History Collection, University of Oklahoma Libraries, Norman, Oklahoma.

Schweinfurth, Kay Parker

2002 Prayer on top of the Earth: The Spiritual Universe of the Plains Apaches. Boulder: University of Colorado Press.

Silverhorn, James

1967 Interview September 28. Doris Duke Oral History Collection, 39, T-146. Western History Collection, University of Oklahoma Libraries, Norman, Oklahoma.

Stokely, Michelle D.

2014 Black Bear's Calendar: Picturing Southern Plains History. Great Plains Quarterly 34(4):341363.

2015 Picturing the People: Kiowa, Comanche and Plains Apache Postcards. Plains Anthropologist 60:99-123.

Swan, Daniel c. and Michael P. Jordan

2011 Tipis and the Warrior Tradition. In Tipi Heritage of the Great Plains, Nancy B. Rosoff and Susan Kennedy Zeller, eds., pp.145-163. University of Washington Press, Seattle.

Szabo, Joyce M.

2007 Art from Fort Marion: The Silberman Collection. Norman, University of Oklahoma Press.

2011 Imprisoned Art, Complex Patronage: Plains Drawings by Howling Wolf and Zotom at the Autry National Center. Santa Fe, School for Advanced Research Press.

Vestal, Stanley

1957 The History of the Tipi. In Indian Tipi Its History, Construction and Use, Reginald Laubin and Gladys Laubin, pp. 3-14. University of Oklahoma Press, Norman. 
Zeller, Susan Kennedy

2011 The Rain-in-the-Face Tipi Liner. In Tipi Heritage of the Great Plains, Nancy B. Rosoff and Susan Kennedy Zeller, eds., pp.77-97. University of Washington Press, Seattle. 